\title{
Association between adiponectin rs17300539 and rs266729 gene polymorphisms with serum adiponectin level in an Iranian diabetic/pre-diabetic population
}

\author{
Helma Karimi ${ }^{1}$, Masoumeh Nezhadali ${ }^{1}$, Mehdi Hedayati $^{2}$ \\ ${ }^{1}$ Department of Biology, Islamshahr Branch, Islamic Azad University, Islamshahr, Iran; ${ }^{2}$ Cellular and Molecular \\ Endocrine Research Center, Research Institute for Endocrine Sciences, Shahid Beheshti University of Medical Science, \\ Tehran, Iran \\ E-mail:ma_nejadali@yahoo.com
}

\begin{abstract}
Objective. Adiponectin is an adipokine that is mostly secreted from adipose tissues and has a significant role in the improvement of insulin resistant and type 2 diabetes mellitus (T2DM). This study is conducted to examine the association of rs17300539 and rs266729 with T2DM and serum adiponectin level in Iranian population.

Method. A case-control study was conducted on 80 individuals with fasting plasma glucose $(\mathrm{FPG})>100(\mathrm{mg} / \mathrm{dl})$ as diabetic-pre-diabetic group, and 80 individuals with fasting plasma glucose 70-100 (mg/dl) as control group. DNA extraction was done on samples and genotyping method was performed by PCR-RFLP.

Result. The frequency of GA genotype in rs17300539 (diabetic/pre-diabetic 35.5\%, control $11.3 \%,(\mathrm{OR}[95 \% \mathrm{CI}]=4.18[1.8-9.6] ; \mathrm{p}=0.001)$ and allele A (diabetic/pre-diabetic 31\%, control 9\%, (OR $[95 \% \mathrm{CI}]=4.67[2-10.7])$ was significantly more in diabetic/pre-diabetic group compared to control group. The difference in the genotype frequency for rs266729 in diabetic group compared to that in control was not significant. The levels of adiponectin in diabetic cases had no difference compared to the control group in both polymorphisms. The rs 266729 was not associated with any metabolic parameter except waist circumference $(\mathrm{p}=0.03)$, however, rs17300539 shows association only with fasting plasma glucose, triglyceride, and total cholesterol $(p=0.007,0.039,0.0032$, respectively).

Conclusion. Our findings showed that there is an association between rs17300539 with the increase of T2DM but rs266729 showed no association with the risk of T2DM. Allele A of rs 17300539 increased the risk of diabetes. There is no association between adiponectin level and both polymorphisms.
\end{abstract}

Key words: diabetes mellitus type 2, obesity, polymorphism, adipose tissue, rs17300539

The role of the white adipose tissue (WAT) solely as an energy storage has been changed ( $\mathrm{Xu}$ et al. 2017). Adipose tissue is known as an endocrine organ that synthesizes proteins with hormonal properties (Sheng and Yang 2008). Adiponectin is one of these proteins, which modulates a number of metabolic processes via the activation of 5'-adenosine monophosphate-activated protein kinase (AMPK) and peroxisome proliferator activated receptor- $\alpha$ (PPAR- $\alpha$ ). This adipokine is an adipocyte-specific hormone known to be involved in a variety of metabolic, antiinflammatory, and vasoprotective activities (Bouzid

Corresponding author: Masoumeh Nezhadali, Department of Biology, Islamshahr Branch, Islamic Azad University, Islamshahr, Iran; e-mail: ma_nejadali@yahoo.com. 
et al. 2016). It has also been reported that adiponectin play a role in the pathogenesis of obesity and type 2 diabetes (T2DM). The lower plasma adiponectin concentrations have been detected in obese patients and patients with insulin resistance when compared to the healthy non-obese individuals. It has also been reported that low adiponectin concentration is connected with T2DM (Aleidi et al. 2014; Yamamoto et al. 2014; Abdalla and Soon 2017).

Adiponectin is a 244 amino acid protein that is encoded by ADIPOQ gene. Adiponectin gene contain three exons and 2 introns spanning $17 \mathrm{~kb}$. AdipoQ gene located on the region $3 \mathrm{q} 27$ and this chromosomal region is a susceptible locus for T2DM and metabolic syndrome (Vasseur et al. 2002; Eissa 2016).

In 1988, a multifaceted metabolic abnormality consisted of insulin resistance with compensatory hyperinsulinemia, T2DM, hypertension, and hyper cholesterolemia has been described by Reaven (1988). Today, this syndrome is known as Reaven syndrome. The term "Metabolic Syndrome" is being used by WHO (World Health Organization) and International Diabetes Federation (IDF) to define all these complications. It has been predicted that about $20-25 \%$ of the world's population are suffering from the metabolic syndrome (Ogedengbe et al. 2016).

T2DM manifests individuals who have more potential of obesity (inactivity) due to their life style as well as appropriate genetic factors. The pathology of the disease is defined by hyperglycemia that is caused by lack or inappropriate response to insulin or insulin production (Al-Azzam et al. 2014). Patients with T2DM often have complex metabolic abnormalities such as hyperinsulinemia, hyperglycemia, and dyslipidemia, which can induce insulin resistance (Cefalu 2001). Insulin resistance is characterized by a diminished ability of insulin-sensitive tissues to take up and metabolize glucose in response to insulin. There is evidence that proved defects in the insulin-signaling pathway may contribute to insulin resistance in humans (Vollenweider et al. 2002). The insulin resistance, obesity, and pregnancy are the most significant causes of $\beta$-cell mass increases. Many studies have reported a reduction in $\beta$-cell volume of patients with T2DM (Cho et al. 2011; Lo et al. 2014).

A meta-analysis study done on white population, East Asians, Asian Indians, African Americans, and Native Americans has confirmed that the higher level of adiponectin is associated with lower risk of T2DM (Davis et al. 2015).

Studies have shown that genetic variants in adiponectin gene were associated with type 2 diabetes in Africans (Olckers et al. 2007), African Ameri- cans (Ukkola et al. 2005) and north India (Prakash et al. 2015). Studies concerning the polymorphisms of adiponectin gene performed on Korean Taiwanese population have shown that there is no association between rs266729 and T2DM (Hsiao et al. 2016). The $-11377 \mathrm{C}>\mathrm{G}$ (rs266729) might be a risk factor for T2DM in European population (Han et al. 2011), and asserted that -11377 is a low-penetrant risk factor for developing T2DM (Gong et al. 2010). In China, especially obese patient (Li et al. 2013), studies have shown that rs266729 has strong correlation with T2DM. The association of rs17300539 with T2DM has also been observed in Iranian population (Hasani-Ranjbar et al. 2012). Our study is conducted to examine the association of rs17300539 and rs266729 in the adiponectin gene with diabetes using participants with no drug consumption of diabetes. Previous studies have proven that thiazolidinedione drug (TZD) increases adiponectin level ( $\mathrm{Yu}$ et al. 2002). In the present study, we investigated the cases without intervention of antidiabetic drugs for better understanding the genetic effects of the polymorphisms on T2DM in Iranian population.

\section{Materials and Methods}

Setting and participants. A case control study was conducted on 80 participants used as a diabetic/pre-diabetic (T2DM/IFG) group holding fasting plasma glucose (FPG) higher than $100 \mathrm{mg} / \mathrm{dl}$ and 80 participants as control (healthy) group holding FPG $70-100 \mathrm{mg} / \mathrm{dl}$. The diabetes and pre-diabetes diagnosis was according to a classification done by an expert committee (Alberti et al. 2003). The participants were clinically diagnosed for diabetes under the supervision of two specialists and then referred to the laboratory of the same hospital (Booali, Toos, Zanjan hospital, pars). In general, two categories of people referred to the clinic. The one who came with their test results and they had the criteria of a healthy participant. The second who distinguished by doctor as a diabetic/pre-diabetic case. After the confirmation of doctor that whether the participants have the criteria of being in each of the groups, the participants were introduced to our team. The aim of the study was explained to all the participants. If they were consent to participate in the study, the written consents were obtained from all the cases. Then the physical measurements, filling the questionnaire and finally blood sampling was done on each of the participants. The fasting venous blood samples were collected from both groups after an overnight fast of 12-14 h to measure FPG. The FPG test was taken 
twice from the participants. The body mass index (BMI) was measured using the protocol followed by the WHO (Flegal et al. 2014). The blood samples (5 $\mathrm{ml}$ ) were taken from participants, then used for DNA extraction, and other $5 \mathrm{ml}$ in tubes containing EDTA for adiponectin and biochemical analysis. The DNA extraction was performed by salting out method (Miller et al. 1988). The inclusion criteria were both genders having FPG $<100 \mathrm{mg} / \mathrm{dl}$ and a normal health condition for control group and FPG $>100 \mathrm{mg} / \mathrm{dl}$ for diabetic/pre-diabetic group. The exclusion criteria were drug consumption for both groups, known disease such as cancer, a well-known diabetic patient, liver disease, kidney disease, pregnancy, heart disease and any kind of infection.

Ethical approval. All procedures performed in studies involving human participants were in accordance with the ethical standards of the institutional and/or national research committee and with the 1964 Helsinki declaration and its later amendments or comparable ethical standards. The whole 160 questionnaire and informed consents is available if requested.

SNPs rs17300539 and rs266729 genotyping. For detection of SNP in the adiponectin gene, genotyping was performed using PCR-RFLP (restriction fragment length polymorphism) method. PCR method (polymerase chain reaction) was performed with total volume of $25 \mu$ l. The reaction consists of $1 \lambda$ genomic DNA, $12.5 \mu$ l Master mix (dNTP, tag polymerase and $\left.\mathrm{MgCl}_{2}\right), 0.9 \mu \mathrm{l}$ forward primer and $0.9 \mu \mathrm{l}$ reverse primer.

We used the following forward primer 5'TAAGG/ GAGAC/ATCGG/TGAAAC_3" and reverse primer 5'TAACGCTCTCCTTCCCATA_3' for rs17300539 and rs266729. We obtained the primers from CinnaGen Company. The primers were designed using Gene runner software. We multiply a sequence of 296 base pair of adiponectin gene by Thermal cycler. The whole PCR process is made up of 3 steps. The initial step included denaturation at $94^{\circ} \mathrm{C}$ for $5 \mathrm{~min}$. Second step, denaturation at $94^{\circ} \mathrm{C}$ for $45 \mathrm{~s}$, annealing at $65^{\circ} \mathrm{C}$ for $45 \mathrm{~s}$ and extension at $72^{\circ} \mathrm{C}$ for $1 \mathrm{~min}$. This step was repeated for 30 cycles. Last step included the final extension at $72^{\circ} \mathrm{C}$ for $10 \mathrm{~min}$. Finally, the PCR product was a 296 base pair length. The quality of the PCR product was verified using $8 \%$ acrylamide gel electrophoresis.

In order to evaluate rs17300539, PCR product was digested by HhaI restriction enzyme. Total volume of the mixture was $0.4 \mu \mathrm{l} \mathrm{HhaI,} 4 \mu \mathrm{l}$ PCR product, $0.4 \mu \mathrm{l}$ purified water and incubated for $16 \mathrm{~h}$ at $37^{\circ} \mathrm{C}$. CG genotype was digested into 3 fragments with the cor- responding lengths $296 \mathrm{bp}, 183 \mathrm{bp}$ and $113 \mathrm{bp}$. GG genotype was digested into 2 fragments with $183 \mathrm{bp}$ and $113 \mathrm{bp}$ lengths. CC was digested into one fragment with 296 bp length.

In order to evaluate rs266729, PCR products were digested by MSPI restriction enzyme. We incubated the mixture with $0.6 \mu \mathrm{l}$ enzyme, $4 \mu \mathrm{l}$ PCR product, $0.4 \mu \mathrm{l}$ purified water for $5 \mathrm{~h}$ at $37^{\circ} \mathrm{C}$. AA genotype was digested into 1 fragment with 296 bp length, AG heterozygous genotype was digested into 3 fragments with the corresponding lengths $296 \mathrm{bp}, 167 \mathrm{bp}, 129 \mathrm{bp}$ and GG genotype was digested into 2 fragments (296bp, 167 bp). HOMA-IR was determined using current equation:

HOMA-IR $=$ fasting insulin $(\mathrm{mU} / \mathrm{L}) \times$ fasting plasma sugar $(\mathrm{mM} / \mathrm{L}) / 22.5$.

To define insulin resistance (IR), a threshold of 2.6 was used based on previous study in the current study population (Tohidi et al. 2014).

Clinical and biochemical measurements. The levels of adiponectin and insulin hormone were measured using commercially available human ELISA kit (Mercodia Company, Sweden). Determination of adiponectin level was done by ELISA kit using a purified immunoglobulin $\mathrm{G}$ (IgG) against a specific determinant on human adiponectin molecule and a mouse anti-adiponectin antibody conjugated to horseradish peroxidase (HRP) used for detection. The levels of triglyceride, total cholesterol, HDL-cholesterol (HDL-C) was measured by enzymatic method (Eshraghi et al. 2007). The LDL-cholesterol (LDL-C) was calculated according to the method developed by Friedewald (Mente et al. 2013).

Data management and statistical analysis. All continuous data showing normal distribution are expressed as mean $\pm \mathrm{SD}$, skewed parameters as median, interquartile 25-75\% (IQ25-75), and categori$\mathrm{cal}$ variables are expressed in percentage. The comparisons between the studied groups were analyzed using Student's t-test or Mann-Whitney test depending on distribution normality or $\chi^{2}$ and Fischer exact test for categorical variables. Relationships between adiponectin and other variables were presented as Spearman's rank correlation coefficients. Genotype distribution in controls was checked using HardyWeinberg equilibrium ( $p>0.05)$. A logistic regression model was used to estimate the odds ratio (OR) of genotypes with diabetes. SPSS software version 2.0 was used for data analysis. P-value $<0.05$ was considered as statistically significant.

The datasets generated during and/or analyzed during the current study are available from the corresponding author on reasonable request. 


\section{Results}

The levels of the total adiponectin in serum ranged from $2.30 \mathrm{mg} / \mathrm{l}$ to $24.80 \mathrm{mg} / \mathrm{l}$. The serum concentrations of adiponectin in women $(3.00-24.80 \mathrm{mg} / \mathrm{l})$ were significantly higher $(\mathrm{p}=0.006)$ than those in men $(2.30-17.00 \mathrm{mg} / \mathrm{l})$. The results show that the mean of adiponectin is $6.6 \mu \mathrm{g} / \mathrm{ml}$ in diabetic/pre-diabetic cases compared to $7.4 \mu \mathrm{g} / \mathrm{ml}$ in control group $(\mathrm{p}=0.115)$. So, statistically there is no significant difference concerning adiponectin between these two groups. Furthermore, the association between rs266729 and T2DM is not statistically significant. The Table 1 also shows that there is a significant association between rs17300539 and T2DM ( $\mathrm{p}=0.001)$. The frequency of AA genotype is very low in the studied population, where the frequency of this genotype is $2.6 \%$ in T2DM/IFG cases, however, this genotype is not observed in control group. Therefore, OR is not calculated for this genotype. There was a significant difference in the frequency of GA genotype between diabetic/pre-diabetic and control group (by 3 folds) (35.5\% for diabetic/pre-diabetic group, $11.3 \%$ for controls) $[\mathrm{CI}=95 \%, \mathrm{OR}=4.18(1.8-9.6) ; \mathrm{p}=0.001]$. Analysis of the data shows that GA genotype increases the risk of T2DM. The frequency of GG genotype is more in control cases ( $88.8 \%$ for diabetic/pre-diabetic group, $62 \%$ for controls). It seems that GG genotype shows protective effect against the risk of T2DM in comparison to other genotypes $[\mathrm{CI}=95 \%, \mathrm{OR}=0.21(0.1-$ $0.5) ; \mathrm{p}<0.001]$. The frequency of allele $\mathrm{A}$ is more in diabetic cases approximately 4 -fold change $[\mathrm{CI}=95 \%$, $\mathrm{OR}=2-10.7 ; \mathrm{p}<0.001]$. The results show that allele $\mathrm{A}$ in rs17300539 is associated with the risk of T2DM. The frequency of CG, CC mutant genotype is not signifi- cantly different between diabetic/pre-diabetic and control groups (32\% for diabetic/pre-diabetic group, $29 \%$ for controls and $44 \%$ for diabetic/pre-diabetic group, 50\% for controls; respectively) and there was not significant association between genotypes of rs266729 and T2DM. Meanwhile, the frequency of allele $\mathrm{G}$ shows no significant difference between the two groups $(\mathrm{p}=0.43)$ (Table 1$)$.

The biochemical variables are studied in every genotype. The proportion of people who have AA genotype in rs17300539 and GG genotype in rs266729 are rare. Therefore, they are ignored from the comparison (Table 2).

Additionally, the variables of FPG, triglyceride and total cholesterol had significant association with rs17300539, respectively $(\mathrm{p}=0.007,0.039,0.0032$; respectively) but the other variables show no association with rs17300539 (Table 2). Furthermore, both variables waist circumference (WC) is significantly associated with rs266729 while the other variables show no association with rs266729 (Table 2).

Finally, we found that adiponectin level was negatively correlated with BMI, WC, insulin and HOMAIR ( $\mathrm{p}=0.017,0.001,0.012,0.002$; respectively) and these parameters have significant association with adiponectin level. This means that when adiponectin level increases, BMI, WC, insulin and HOMA-IR levels decrease (Table 3 ).

\section{Discussion}

In the current study, there is no significant association between rs266729 in adiponectin gene and the genotypes GG, GC, and CC of rs 266729 with the risk of T2DM. The frequency of the genotypes GG, GC

Table 1

Allele and genotype frequencies in groups.

\begin{tabular}{llcccc}
\hline & & $\begin{array}{c}\text { T2DM/IFG } \\
(\mathbf{n = 8 0})\end{array}$ & $\begin{array}{c}\text { Controls } \\
\mathbf{N}(\mathbf{n}=\mathbf{8 0}) \\
\mathbf{N}(\%)\end{array}$ & p-value & $\begin{array}{c}\text { OR } \\
(\mathbf{9 5} \% \mathbf{C I})\end{array}$ \\
\hline rs266729 & G & $36(23.1)$ & $31(19.4)$ & 0.436 & $1.29(0.68-2.43)$ \\
& CC & $44(56.4)$ & $50(62.5)$ & 0.538 & $1.22(0.6-2.3)$ \\
& GG & $32(41)$ & $29(36.3)$ & 0.538 & $1.22(0.6-2.3)$ \\
rs17300539 & GG & $2(2.6)$ & $1(1.3)$ & 0.554 & $2.07(0.2-23.4)$ \\
& GG & $49(62.8)$ & $71(88.8)$ & $<0.001$ & $0.21(0.1-0.5)$ \\
& GA & $27(35.5)$ & $9(11.3)$ & $0.001^{*}$ & $4.18(1.8-9.6)$ \\
& AA & $2(2.6)$ & $0(0)$ & - & - \\
\hline
\end{tabular}

Abbreviations: T2DM/IFG - diabetic/pre-diabetic group; T2DM - type 2 diabetes mellitus; IFG - impaired fasting glucose. 
Table 2

Anthropometric and metabolic characteristics according to rs266729 and rs17300539 genotypes.

\begin{tabular}{|c|c|c|c|c|c|c|}
\hline \multirow[b]{2}{*}{ Variable } & \multicolumn{2}{|c|}{ rs 17300539} & \multicolumn{4}{|c|}{ rs 266729} \\
\hline & $\begin{array}{c}\text { GG } \\
(n=120)\end{array}$ & $\underset{(n=36)}{G A}$ & p-value & $\begin{array}{c}C C \\
(n=94)\end{array}$ & $\underset{(n=61)}{C G}$ & p-value \\
\hline Age (year) & $46 \pm 14.6^{\dagger}$ & $47.1 \pm 15.7)$ & 0.697 & $45.4 \pm 14.5$ & $46.7 \pm 15.4$ & 0.654 \\
\hline BMI $\left(\mathrm{kg} / \mathrm{m}^{2}\right)$ & $26.7 \pm 5.8$ & $26 \pm 5.1$ & 0.575 & $25.8 \pm 5$ & $27.8 \pm 6.5$ & 0.575 \\
\hline $\mathrm{WC}(\mathrm{cm})$ & $100.3 \pm 12.9$ & $96.3 \pm 13.5$ & 0.126 & $96.7 \pm 12.8$ & $102.2 \pm 13.5$ & $0.030^{*}$ \\
\hline Hip (cm) & $101.7 \pm 17.1$ & $101 \pm 11.7$ & 0.824 & $101.2 \pm 17.8$ & $101.8 \pm 12.3$ & 0.839 \\
\hline HDL (mg/dl) & $55.5 \pm 34.4$ & $49.4 \pm 28.9$ & 0.117 & $54.5 \pm 32.5$ & $50.6 \pm 33.1$ & 0.570 \\
\hline $\operatorname{LDL}(\mathrm{mg} / \mathrm{dl})$ & $112.9 \pm 38.4$ & $108.6 \pm 31.4$ & 0.630 & $116.3 \pm 40.5$ & $102.8 \pm 30.7$ & 0.107 \\
\hline $\mathrm{TC}(\mathrm{mg} / \mathrm{dl})$ & $170 \pm 45.1$ & $191.4 \pm 46.1$ & $0.032^{*}$ & $177.3 \pm 45.5$ & $180.8 \pm 48.2$ & 0.729 \\
\hline TG (mg/dl) & $109(90.5-167)^{\ddagger}$ & $151(102.5-212)$ & $0.039^{*}$ & $112(91-173)$ & $148(95.5-200.5)$ & 0.323 \\
\hline FPG (mg/dl) & $96.5(87-135.2)$ & $127.5(97.7-168.5)$ & $0.001^{*}$ & $101(88.5-142.5)$ & $106(88-145.5)$ & 0.668 \\
\hline Insulin (mU/l) & $9(5.7-15.2)$ & $8(6.2-12.4)$ & 0.778 & $8.4(5.4-14.4)$ & $9.5(6.2-15.1)$ & 0.498 \\
\hline $\operatorname{HOMA}\left(\mathrm{mol} \times \mu \mathrm{U} / \mathrm{I}^{2}\right)$ & $2.3(1.4-4.2)$ & $2.9(1.8-3.9)$ & 0.099 & $2.4(1.4-4.2)$ & $2.6(1.6-3.8)$ & 0.431 \\
\hline Adiponectin $(\mu \mathrm{g} / \mathrm{ml})$ & $6.7(5.4-10.2)$ & $7.9(4.9-11.2)$ & 0.768 & $7.7(5.4-11.4)$ & $6.6(5.2-9.2)$ & 0.099 \\
\hline sex & & & 0.304 & & & 0.460 \\
\hline male & $42(35)^{\$}$ & $16(44.4)$ & & $33(35.1)$ & $25(41)$ & \\
\hline female & $78(65)$ & $20(55.6)$ & & $61(64.9)$ & $36(59)$ & \\
\hline
\end{tabular}

Abbreviations: BMI - body mass index; WC - waist circumference; HDL - high density lipoprotein; LDL - low density lipoprotein; TC - total cholesterol; TG - triglyceride; FPG - fasting plasma glucose; HOMA-IR - Homeostasis Model Assessment of Insulin Resistance. ${ }^{\dagger}$ Mean \pm SD; ${ }^{*}$ Median (IQR); ${ }^{\text {n }}$ (\%); Significant considered as $\mathrm{p}<0.05$.

Table 3

Spearman rank correlations coefficients of the adiponectin with different clinical parameters in participants.

\begin{tabular}{|c|c|c|c|}
\hline Variable & Correlation & $95 \%$ CI & p-value \\
\hline Age (year) & -0.077 & $(-0.307,0.166)$ & 0.562 \\
\hline BMI $\left(\mathrm{kg} / \mathrm{m}^{2}\right)$ & -0.310 & $(-0.548,-0.013)$ & $0.017^{\star}$ \\
\hline $\mathrm{WC}(\mathrm{cm})$ & -0.440 & $(-0.633,-0.201)$ & $<0.001^{*}$ \\
\hline Hip (cm) & -0.199 & $(-0.450,0.092)$ & 0.131 \\
\hline HDL (mg/dl) & 0.057 & $(-0.225,0.310)$ & 0.667 \\
\hline $\mathrm{LDL}(\mathrm{mg} / \mathrm{dl})$ & 0.017 & $(-0.255,0.285)$ & 0.901 \\
\hline TC (mg/dl) & -0.124 & $(-0.371,0.152)$ & 0.351 \\
\hline TG (mg/dl) & -0.185 & $(-0.445,0.064)$ & 0.160 \\
\hline FPG (mg/dl) & -0.017 & $(-0.285,0.248)$ & 0.898 \\
\hline $\operatorname{HOMA}\left(\mathrm{mol} \times \mu \mathrm{U} / \mathrm{I}^{2}\right)$ & -0.255 & $(-0.409,-0.082)$ & $0.002^{*}$ \\
\hline Insulin (mU/l) & -0.204 & $(-0.371,-0.034)$ & $0.012^{*}$ \\
\hline \multicolumn{4}{|c|}{$\begin{array}{l}\text { Abbreviations: BMI - body mass index; WC - waist } \\
\text { circumference; HDL - high-density lipoprotein; LDL - low- } \\
\text { density lipoprotein; TC - total cholesterol; TG - triglyceride; } \\
\text { FPG - fasting plasma glucose; HOMA-IR - Homeostasis Model } \\
\text { Assessment of Insulin Resistance. } \\
\text { Values are expressed as Mean } \pm \text { Standard Deviation. }{ }^{*} \mathrm{p}<0.05 \text {. }\end{array}$} \\
\hline
\end{tabular}

and $\mathrm{CC}$ shows significant difference between control and T2DM/IFG groups. Previous studies performed on Jahrom city in Iran (Erfanian et al. 2016), India (Khan et al. 2017) and Italian population (Chiodini et al. 2010) were consistent with our study. On the other hand, studies that were carried out in India ( Ramya et al. 2013), Finnish Diabetes Prevention Study (Siitonen et al. 2011), and Iraqi population (Kaftan and Hussain 2015) showed that rs266729 had association with T2DM. In Finnish Diabetes Prevention Study, allele C of rs266729 was associated with an increased adjusted hazard ratio for developing T2DM.

In our study we observed significant association between rs17300539 and T2DM. The frequency of genotypes AA, AG and GG had significant difference between diabetic and non-diabetic groups. Studies performed on Gargano area in Italy (Menzaghi et al. 2010) and meta-analysis (Chu et al. 2013) have shown that rs17300539 increased the risk of T2DM and also validated that rs266729 is a low-penetrate risk factor of T2DM which is consistent with our study. Our results showed that adiponectin level has no significant association with rs17300539. 
We concluded that the frequency of GA genotype in rs17300539 is more in T2DM/IFG cases compared to healthy group and allele A of rs17300539 increases the risk of T2DM. In a study performed on a large group of European origin in Verona, FleurbaixLaventie and Lille childhood obesity cohort showed that carriers of AA and GA genotypes had higher level of adiponectin and BMI and were more prevalent to obesity. This study showed consistent results with ours (Morandi et al. 2010).

Additionally, we concluded that adiponectin level is not associated with rs266729 and rs17300539. In a study performed on Hispanic-American, Texas (An et al. 2012) and MONICA/KORA (Cooperative Health Research in the Region of Augsburg) (Laumen et al. 2009), rs17300539 was associated with plasma adiponectin level which was inconsistent with our study. Furthermore, rs266729 was associated with adiponectin level in north Indian population (Khan et al. 2017). However, the genotype GG of rs 266729 significantly increased the risk of T2DM with CVD in Iraqi population (Ismail et al. 2016).

Adiponectin level was negatively correlated with BMI as it has been observed in people enrolled in GISSI-HF trial (Masson et al. 2011; Aleidi et al. 2014). The adiponectin level also negatively associated with BMI and insulin level in a study that was done on an Indian population (Renju et al. 2012) and a negative correlation between adiponectin level with WC and BMI was also found in a study done in Jordanian population (Aleidi et al. 2014). Given the fact that adiponectin is a major modulator of insulin action for its role in enhancing insulin sensitivity.

In general, it seems that the association of rs 266729 with T2DM is more observed in Asian population but not in other populations. Also, rs266729 was associated with waist and BMI as shown in our results. In a study conducted on Arabian families, rs266729 was associated with body weight, WC and BMI (Zadjali et al. 2013).

Finally, we concluded that rs17300539 had association with FPG. Additionally, rs17300539 was associated with plasma adiponectin and glucose fasting in African-American cohort where the association of rs17300539 with FPG was confirmed in our study (An et al. 2012). We also discovered that SNP-11377 (rs266729) had no association with adiponectin and insulin levels, which is not consistent with the study done on Hong Kong Chinese population (Ong et al. 2010; Li et al. 2013). No association of rs266729 with HOMA-IR and adiponectin level that we found, was also discovered in another study in a multiethnic population assembled in Canada (Mente et al. 2013). In a study named Erasmus Rucphen Family study in Netherland (Henneman et al. 2010) and in European origin (Morandi et al. 2010), there was an association between rs17300539 and HOMA-IR in that is not consistent to our study.

In summary, our results showed that there is association between rs17300539 and allele A with the increase of T2DM, but the genotypes of rs 266729 were not associated with the risk of T2DM.

\section{Acknowledgment}

The authors express their sincere thanks to the Cellular and Molecular Research Center for providing all laboratory equipment, Dr Laleh Ghanei, Endocrinologist and Metabolism Specialist, Dr. Mehran Zaman Zadeh, Member of Iranian Association for Diabetes and Endocrinology and Member of the American Diabetes Association (ADA), for their guidance in the subject, and special thanks from Booali Hospital stuff for their assistance. This research was not supported by any specific grant from public funding agency, commercial or not-for-profit sector.

\section{References}

Abdalla MMI, Soon SC. Salivary adiponectin concentration in healthy adult males in relation to anthropometric measures and fat distribution. Endocr Regul 51, 185-192, 2017.

Alberti KG, Genuth S, Bennett P, Buse J, Defronzo R, Hahn R, Kitzmiller J, Knowler WC, Lebovitz H, Lernmark A, Nathan D, Palmer J, Rizza R, Saudek C, Shaw J, Steffes M, Stern M, Tuomilehto J, Zimmet P; Expert Committee on the Diagnosis and Classification of Diabetes Mellitus. Follow-up report on the diagnosis of diabetes mellitus. Diabetes Care 26, 3160-3167, 2003.

Aleidi S, Issa A, Bustanji H, Khalil M, Bustanji Y. Adiponectin serum levels correlate with insulin resistance in type 2 diabetic patients. Saudi Pharm J 23, 250-256, 2014.

Al-Azzam SI, Khabour OF, Alzoubi KH, Ghanma MW, Alhasan AY. The role of TNF- $a$ G-308A promoter polymorphism in glycemic control in Type 2 diabetes patients. J Endocrinol Invest 37, 113-118, 2014. 
An SS, Hanley AJ, Ziegler JT, Brown WM, Haffner SM, Norris JM, Rotter JI, Guo X, Chen YD, Wagenknecht LE, Langefeld CD, Bowden DW, Palmer ND. Association between ADIPOQ SNPs with plasma adiponectin and glucose homeostasis and adiposity phenotypes in the IRAS Family Study. Mol Genet Metab 107, 721-728, 2012.

Bouzid T, Hamel FG, Lim JY. Role of adipokines in controlling insulin signaling pathways in type-2 diabetes and obesity. Current and future perspectives. Int J Diabetes Res 5, 75-85, 2016.

Cefalu WT. Insulin resistance: cellular and clinical concepts. Exp Biol Med (Maywood) 226, 13-26, 2001.

Chiodini BD, Specchia C, Gori F, Barlera S, D’Orazio A, Pietri S, Crociati L, Nicolucci A, Franciosi M, Signorini S, Brambilla P, Grazia Franzosi M; GISSI Prevenzione Investigators; SiBioC-GISSI Prevenzione Group. Adiponectin gene polymorphisms and their effect on the risk of myocardial infarction and type 2 diabetes: an association study in an Italian population. Ther Adv Cardiovasc Dis 4, 223-230, 2010.

Cho J, Kim J, Shin J, Shin J, Yoon K. $\beta$-cell mass in people with type 2 diabetes. J Diabetes Investig 2, 6-17, 2011.

Chu H, Wang M, Zhong D, Shi D, Ma L, Tong N, Zhang Z. AdipoQ polymorphisms are associated with type 2 diabetes mellitus: a meta-analysis study. Diabetes Metab Res Rev 29, 532-545, 2013.

Davis SK, Gebreab SY, Xu R, Riestra P, Khan RJ, Sumner AE, Hickson D, Bidulescu A. Association of adiponectin with type 2 diabetes and hypertension in African American men and women: the Jackson Heart Study. BMC Cardiovasc Disord 15, 13, 2015.

Eissa A. Investigate the relation between Adiponectin gene variants and cardiovascular comorbidities and diabetes. Int J Health Sci (Qassim) 10, 183-189, 2016.

Erfanian S, Moradzadeh M, Solhjoo K, Jahromi AS. Data describing the association between rs266729 polymorphism in adiponectin promoter gene and Type 2 Diabetes Mellitus. Data Brief 9, 1138-1140, 2016.

Eshraghi P, Hedayati M, Daneshpour M, Mirmiran, P, Azizi F. Association of body mass index and Trp64Arg polymorphism of the beta3-adrenoreceptor gene and leptin level in Tehran Lipid and Glucose Study. Br J Biomed Sci 64, 117-120, 2007.

Flegal KM, Kit BK, Graubard BI. Body mass index categories in observational studies of weight and risk of death. Am J Epidemiol 180, 288-296, 2014.

Gong M, Long J, Liu Q, Deng HC. Association of the ADIPOQ rs17360539 and rs266729 polymorphisms with Type 2 diabetes: A meta-analysis. Mol Cell Endocrinol 325, 78-83, 2010.

Han LY, Wu QH, Jiao ML, Hao YH, Liang LB, Gao LJ, Legge DG, Quan H, Zhao MM, Ning N, Kang Z, Sun H. Associations between single nucleotide polymorphisms $(+45 \mathrm{~T}>\mathrm{G},+276 \mathrm{G}>\mathrm{T},-11377 \mathrm{C}>\mathrm{G},-11391 \mathrm{G}>\mathrm{A})$ of adiponectin gene and type 2 diabetes mellitus: a systematic review and meta-analysis. Diabetologia 54, 2303-2314, 2011.

Hasani-Ranjbar S, Amoli M M, Tabatabaei-Malazy O, Rumi Y, Tavakkoly-Bazzaz J, Samimi H, Abbasifarid E. Effect of adiponectin gene polymorphisms on waist circumference in patients with diabetes. J of Diabetes and Metab Dis, 11, 14, 2012.

Henneman P, Aulchenko YS, Frants RR, Zorkoltseva IV, Zillikens MC, Frolich M, Oostra BA, van Dijk KW, van Duijn CM. Genetic architecture of plasma adiponectin overlaps with the genetics of metabolic syndromerelated traits. Diabetes Care 33, 908-913, 2010.

Hsiao TJ, Lin E. A validation study of adiponectin rs266729 gene variant with Type 2 diabetes, obesity, and metabolic phenotypes in a Taiwanese population. Biochem Genet 54, 830-841, 2016.

Ismail JM, Hussain MK, Mohammad HJ. Association of adiponectin gene polymorphism rs266729 with adiponectin levels in type 2 diabetic patients with and without CVD. In AL-NAJAF governorate, IRAQ. Int. J. of Adv. Res 4, 1089-1096, 2016.

Kaftan AN, Hussain MK. Association of adiponectin gene polymorphism rs266729 with type two diabetes mellitus in Iraqi population. A pilot study. Gene 570, 95-99, 2015.

Khan M. M, Sonkar GK, Alam R, Singh S, Mehrotra S, Sonkar SK. Association of ADIPOQ gene variant rs266729 with circulatory adiponectin levels in patients with type 2 diabetes in North Indian population: A casecontrol study. Biomed Pharmacol J 10, 2017.

Laumen H, Saningong AD, Heid IM, Hess J, Herder C, Claussnitzer M, Baumert J, Lamina C, Rathmann W, Sedlmeier EM, Klopp N, Thorand B, Wichmann HE, Illig T, Hauner H. Functional characterization of promoter variants of the adiponectin gene complemented by epidemiological data. Diabetes 58, 984-991, 2009.

Li YY, Yang ZJ, Zhou CW, Wang XM, Qian Y, Xu J, Wang B, Wu J. Adiponectin-11377CG gene polymorphism and type 2 diabetes mellitus in the Chinese population: A meta-analysis of 6425 subjects. PLoS ONE 8, e61153, 2013. 
Lo JC, Ljubicic S, Leibiger B, Kern M, Leibiger IB, Moede T, Kelly ME, Chatterjee Bhowmick D, Murano I, Cohen P, Banks AS, Khandekar MJ, Dietrich A, Flier JS, Cinti S, Bluher M, Danial NN, Berggren PO, Spiegelman BM. Adipsin is an adipokine that improves $\beta$ cell function in diabetes. Cell 158, 41-53, 2014.

Masson S, Gori F, Latini R, Milani V, Flyvbjerg A, Frystyk J, Crociati L, Pietri S, Vago T, Barlera S, Maggioni AP, Tognoni G, Tavazzi L, Omland T, Franzosi MG; GISSI-HF Investigators. Adiponectin in chronic heart failure: influence of diabetes and genetic variants. Eur J Clin Invest 41, 1330-1338, 2011.

Mente A, Meyre D, Lanktree MB, Heydarpour M, Davis AD, Miller R, Gerstein H, Hegele RA, Yusuf S, Anand SS; SHARE Investigators; SHARE-AP Investigators. Causal relationship between adiponectin and metabolic traits: a Mendelian randomization study in a multiethnic population. PLoS One 8, e66808, 2013.

Menzaghi C, Salvemini L, Paroni G, De Bonis C, Mangiacotti D, Fini G, Doria A, Di Paola R, Trischitta V. Circulating HMW adiponectin isoform is heritable and shares a common genetic background with insulin resistance in non diabetic White Caucasians from Italy: evidence from a family-based study. J Intern Med 267, 287-294, 2010.

Miller SA, Dykes DD, Polesky HF. A simple salting out procedure for extracting DNA from human nucleated cells. Nucleic Acids Res 16, 1215, 1988.

Morandi A, Maffeis C, Lobbens S, Bouatia-Naji N, Heude B, Pinelli L, Meyre D, Froguel P. Early detrimental metabolic outcomes of rs17300539-A allele of ADIPOQ gene despite higher adiponectinemia. Obesity (Silver Spring) 18, 1469-1473, 2010.

Ogedengbe S, Ezeani IU, Aihanuwa E. Comparison of clinical and biochemical variables in type 2 diabetes mellitus patients and their first-degree relatives with metabolic syndrome in Benin City, Nigeria: A cross sectional case controlled study. Endocr Regul 50, 32-40, 2016.

Olckers A, Towers GW, van der Merwe A, Schwarz PE, Rheeder P, Schutte AE. Protective effect against type 2 diabetes mellitus identified within the ACDC gene in a black South African diabetic cohort. Metabolism 56, 587-592, 2007.

Ong KL, Li M, Tso AW, Xu A, Cherny SS, Sham PC, Tse HF, Lam TH, Cheung BM, Lam KS; Investigators of the Hong Kong Cardiovascular Risk Factor Prevalence Study. Association of genetic variants in the adiponectin gene with adiponectin level and hypertension in Hong Kong Chinese. Eur J Endocrinol 163, 251-257, 2010.

Prakash J, Mittal B, Awasthi S, Srivastava N. Association of adiponectin gene polymorphism with adiponectin levels and risk for insulin resistance syndrome. Int J Prev Med 6, 31, 2015.

Ramya K, Ayyappa KA, Ghosh S, Mohan V, Radha V. Genetic association of ADIPOQ gene variants with type 2 diabetes, obesity and serum adiponectin levels in south Indian population. Gene 532, 253-262, 2013.

Reaven GM. Banting lecture 1988. Role of insulin resistance in human disease. Diabetes 37, 1595-1607, 1988.

Renju VC, Santha K, Sethupathy S, Koshy M, Marichamy G, Sri Kumaran N. Serum adiponectin and fasting insulin levels in patients with type 2 diabetics. J Pharm Sci Res 4, 1844-1847, 2012.

Sheng T, Yang K. Adiponectin and its association with insulin resistance and type 2 diabetes. J Genet Genomics 35, 321-326, 2008.

Siitonen N, Pulkkinen L, Lindstrom J, Kolehmainen M, Eriksson JG, Venojarvi M, Ilanne-Parikka P, KeinanenKiukaanniemi S, Tuomilehto J, Uusitupa M. Association of ADIPOQ gene variants with body weight, type 2 diabetes and serum adiponectin concentrations: the Finnish Diabetes Prevention Study. BMC Med Genet 12, 5, 2011.

Tohidi M, Ghasemi A, Hadaegh F, Derakhshan A, Chary A, Azizi F. Age- and sex-specific reference values for fasting serum insulin levels and insulin resistance/sensitivity indices in healthy Iranian adults: Tehran Lipid and Glucose Study. Clin Biochem 47, 432-438, 2014.

Ukkola O, Santaniemi M, Rankinen T, Leon AS, Skinner JS, Wilmore JH, Rao DC, Bergman R, Kesaniemi YA, Bouchard C. Adiponectin polymorphisms, adiposity and insulin metabolism: HERITAGE family study and Oulu diabetic study. Ann Med 37, 141-150, 2005.

Vasseur F, Helbecque N, Dina C, Lobbens S, Delannoy V, Gaget S, Boutin P, Vaxillaire M, Lepretre F, Dupont S, Hara K, Clement K, Bihain B, Kadowaki T, Froguel P. Single-nucleotide polymorphism haplotypes in the both proximal promoter and exon 3 of the APM1 gene modulate adipocyte-secreted adiponectin hormone levels and contribute to the genetic risk for type 2 diabetes in French Caucasians. Hum Mol Genet 11, 2607-2614, 2002.

Vollenweider P, Menard B, Nicod P. Insulin resistance, defective insulin receptor substrate 2-associated phosphatidylinositol-3' kinase activation, and impaired atypical protein kinase C (zeta/lambda) activation in myotubes from obese patients with impaired glucose tolerance. Diabetes 51, 1052-1059, 2002.

Xu X, Wen J, Lu Y, Ji H, Su Y, Zhuang J, Su Y, Liu B, Li H, Xu Y. Impact of age on plasma vaspin concentration in a group of normal Chinese people. J Endocrinol Invest, 40(2):143-151, 2017. 
Yamamoto S, Matsushita Y, Nakagawa T, Hayashi T, Noda M, Mizoue T. Circulating adiponectin levels and risk of type 2 diabetes in the Japanese. Nutr Diabetes 4, e130, 2014.

Yu JG, Javorschi S, Hevener AL, Kruszynska YT, Norman RA, Sinha M, Olefsky JM. The effect of thiazolidinediones on plasma adiponectin levels in normal, obese, and type 2 diabetic subjects. Diabetes 51, 2968-2974, 2002.

Zadjali F, Al-Yahyaee S, Hassan MO, Albarwani S, Bayoumi RA. Association of adiponectin promoter variants with traits and clusters of metabolic syndrome in Arabs: family-based study. Gene 527, 663-669, 2013. 